\title{
Diallel Analysis for Seed Yield and Related Traits in an Energy Crop Jatropha curcas
}

(Analisis Dialel Hasil Biji dan Ciri Berkaitan dalam Tanaman Tenaga Jatropha curcas)

\author{
A.K.M. AMINUL ISLAM*, NURINA ANUAR, ZAHIRA YAAKOB, JAHARAH A. GHANI \& MOHAMAD OSMAN
}

\begin{abstract}
Six parents $\left(P_{1}, P_{2}, P_{3}, P_{4}, P_{5}\right.$ and $\left.P_{6}\right)$ half diallel population of Jatropha curcas were evaluated to determine the combining ability, genetic components of variance and heterosis for yield contributing traits. Diallel analysis showed that both additive and dominance gene action was responsible for the genetic regulation of all the traits under study. The cross combination $P_{1} \times P_{3}$ showed the highest positive specific combining ability for seed yield per plant. Combining ability results were also in close agreement with the findings of estimate of genetic components of variance. The seeds per fruit (89\%) and 100-seed weight (93\%) showed maximum narrow sense heritability. Seed yield per plant showed high mid parent $(254.13 \%)$ and better parent $(202.36 \%)$ heterosis in the cross combinations of $P_{2} \times P_{5}$ and $P_{1} \times P_{3}$, respectively. The parents of $P_{1}, P_{2}, P_{3}$ and $P_{5}$ were found to be superior for seed yield components when used in cross. Considering seed production for each plant, the hybrids $P_{1} \times P_{2}, P_{1} \times P_{3}, P_{2} \times P_{5}$ and $P_{4} \times P_{6}$ could be selected for the development of hybrid varieties.
\end{abstract}

Keywords: Breeding; combining ability; fruit yield; heterosis; Jatropha curcas

\section{ABSTRAK}

Enam induk populasi dialel separa Jatropha curcas $\left(P_{1}, P_{2}, P_{3}, P_{4}, P_{5}\right.$ dan $\left.P_{6}\right)$ telah dinilai untuk menentukan keupayaan penggabungan komponen genetik bagi varian dan heterosis, untuk ciri yang menyumbang kepada peningkatan hasil. Analisis dialel menunjukkan bahawa tindakan kedua-dua gen tambah dan dominan adalah berperanan dalam pengaturan genetik bagi kesemua ciri yang dikaji. Gabungan kacukan $P_{1} \times P_{3}$ menunjukkan keupayaan penggabungan spesifik positif paling tinggi untuk penghasilan biji per pokok. Hasil keupayaan penggabungan juga hampir menyamai keputusan anggaran komponen genetik untuk varians. Bilangan biji per buah (89\%) dan berat 100-biji (93\%) menunjukkan keterwarisan deria sempit yang maksimum. Hasil biji per pokok menunjukkan heterosis induk tengah (254.13\%) dan induk baik (202.36\%) yang tinggi, masing-masing dalam gabungan kacukan $P_{2} \times P_{5}$ dan $P_{1} \times P_{3}$. Induk $P_{1}, P_{2}, P_{3}$ dan $P_{5}$ didapati lebih superior apabila digunakan dalam kacukan untuk komponen-komponen penghasilan biji. Dengan mengambil kira penghasilan biji untuk setiap pokok, hibrid $P_{1} \times P_{2}, P_{1} \times P_{3}, P_{2} \times P_{5}$ dan $P_{4} \times P_{6}$ boleh dipilih untuk pembangunan hibrid yang pelbagai.

Kata kunci: Heterosis; Jatropha curcas; keupayaan gabungan; pembiakbakaan; penghasilan buah

\section{INTRODUCTION}

Jatropha curcas L. has drawn attention of a number of researchers for the use of its oil as a commercially feasible alternative to petrol fuel among the oil-bearing trees (Gunaseelan 2009; Mandpe et al. 2005). The main resources of biofuel comprise of grape seed (USA, Germany and France), soybean (USA and Brazil), oil palm (Malaysia), sunflower (Bulgaria, Greece and Spain), wheat (Germany, Denmark and France) and jatropha (Nicaragua and South America) (Jayasingh 2004). The farmers are not financially benefitted from the existing jatropha cultivars due to their low yield. Large gap between possible (15-20 MT) and real yield (5-8 MT) of jatropha cultivar is mainly due to the use of local plant materials (Islam 2011). The selection of better-quality planting materials with high seed yield and oil content from the existing collections and their multiplication for further cultivation may reduce the yield gap (Islam et al. 2009).

In the 20th century, improvement of HYV crop varieties through conventional breeding has considerably augmented farm yield (Evenson \& Gollin 2003). Jatropha is a highly cross-pollinated plant having male to female in the same inflorescence with the ratio of 29:1 (Islam 2011; Sharma \& Kumar 2010). This cross pollination system can be utilized for the development of hybrid variety. Information on nature and magnitude of gene action for yield related traits of jatropha is inadequate. Diallel analysis in $\mathrm{F}_{1}$ hybrids can be directed to get rewarding result for the detection of hereditary information regarding gene action, combining ability as well as dominance association of the parents (Townsend et al. 2013). Such hereditary information is necessary for the planning of successful plant breeding program for jatropha improvement. It is 
essential to select better parents for any efficient breeding program and hybrids to increase the extent of variation for the identification of better genotypes. Combining ability is a potential means to identify the best combiners which may be utilized to accumulate favourable genes for exploiting hybrid vigor (El-Bramawy \& Shaban 2007; Griffing 1956). Hybrid vigor results from the mutual relations of allelic and non-allelic genes which are generally directly and completely associated with heterozygosity (Burton 1968). According to Pal and Sikka (1956) heterosis is a quick, cheap and easy method for increasing crop production. Seed yield of jatropha can be genetically enhanced through development of hybrid variety. Therefore, the present study was under taken to know the nature and extent of gene action, combining ability and heterotic effects of different hybrid combinatios for seed yield and related traits in jatropha.

\section{MATERIALS AND METHODS}

Six parents $\left(\mathrm{P}_{1}, \mathrm{P}_{2}, \mathrm{P}_{3}, \mathrm{P}_{4}, \mathrm{P}_{5}\right.$ and $\left.\mathrm{P}_{6}\right)$ used in the hybridization program were selected on the basis of their genetic diversity and were multiplied by stem cuttings to maintain the purity. The selected parents were originated from three different countries $\left[\mathrm{P}_{1}=\mathrm{CPP} 06\right.$ (Malaysia), $\mathrm{P}_{2}=\mathrm{CPP} 18$ (India), $\mathrm{P}_{3}=\mathrm{CPP01}$ (Indonesia), $\mathrm{P}_{4}=\mathrm{CPP} 05$ (Malaysia), $\mathrm{P}_{5}=\mathrm{CPP0}$ (Malaysia) and $\mathrm{P}_{6}=$ CPP04 (Indonesia)]. At the beginning of the study, 28 candidate plus plants (CPPs) were chosen on the basis of their agro-morphological characters from 487 plant population of 21 accessions derived from eight diverse origins (Malaysia, Indonesia, Thailand, Vietnam, India, Cape Verde, Swaziland and South Africa). The parents were crossed using half diallel crossing scheme excluding reciprocals in the period from July to December 2009 to generate $F_{1}$. The seeds of $F_{1}$ along with self progenies of parents were planted in the polybags $\left(20 \times 9 \times 6 \mathrm{~cm}^{3}\right)$ with the combination of top soil and kitchen compost in the proportion of 50:50. The seeds of $F_{1}$ and their parents were planted to a depth of $3 \mathrm{~cm}$ (Henning 2000) in the polybags and irrigated to saturation thrice in a week. Transplantation of seedlings was completed in the field with a spacing of $3 \times 2 \mathrm{~m}$ in a randomized complete block design with three replications. Thirty days old healthy seedlings were transplanted $(30 \times 30 \mathrm{~cm})$ in a hole at necessary depth. The holes were dug and filled with soil, FYM (3-5 kg), urea (30 g), SSP (120 g) and MP (20 g) (Punia 2007). The required agronomic practices were pursued for establishing an excellent jatropha plantation except irrigation (Jongschaap et al. 2007; Kumar \& Sharma 2008). The plantation was established at Universiti Kebangsaan Malaysia Biofuel Research Station in Kuala Pilah, Malaysia.

The data were recorded on 30 plants selected randomly (10 plants in every block) in each population for eight yield contributing traits in the period from January 2010 to August 2011. The yield contributing traits were inflorescence per plant (IPP), fruits per inflorescence
(FPI), fruits per plant (FPP), seeds per fruit (SPF), seeds per plant (SPP), 100-seed weight (HSW in g), seed yield per plant (SYP in g) and seed oil content (OC\%). Analysis of variance was carried out following the procedure in Panse and Sukhatme (1978) by using statistical package, SAS version 9.01 (2008). The data pertaining to genetic analysis of diallel population (parents and $\mathrm{F}_{1}$ ) were analyzed following the two main approaches viz. Griffing (1956) and Hayman (1954a, 1954b) approaches with modifications of Morley-Jones (1965), often quoted with worked out examples found in several reference literatures (Falconer \& Mackey 1996; Sharma 1988; Singh \& Chaudhary 1985). The percent of heterosis over the mid-parent (MP\%) and heterobeltiosis $(\mathrm{BP} \%)$ were estimated by means of the formulae [(mean of $\mathrm{F}_{1}$ - mean of parents $) /($ mean of parents $)$ $\times 100]$ and $\left[\left(\right.\right.$ mean of $F_{1}-$ mean of better parent $) /($ mean of better parent) $\times 100$ ], respectively (Liang et al. 1971; Shull 1952). The significance of heterosis values were tested by using t-test (Wynne et al. 1970).

\section{RESULTS AND DISCUSSION}

The combining ability, genetic components of variation and heterosis were estimated for yield contributing traits in this study. Considerable genetic variations among the parents were showed by the significant difference among the genotypes. It indicates their respective crosses are also suitable for advance biometrical evaluation of the characters under apprehension (El-Bramawy \& Shaban 2007).

\section{COMBINING ABILITY}

Highly significant $(p<0.01)$ general combining ability (GCA) and specific combining ability (SCA) variances were observed for all the traits. It indicates the extent of equal contribution of additive, dominance and interaction effects of genes for the expression of these characters (Table 1). High extent of general combining ability was found for the maximum traits. GCA/SCA variance was less than 1.0 for inflorescence per plant indicates preponderance of non-additive genetic effects over additive genetic effects. This ratio was greater than 1.0 for the remaining yield related traits and the percent of oil content in seeds (Table 1 ), presenting the prevalence of additive gene action compared to non-additive gene action involving in the genetic control of these characters. The higher influence of non-additive genetic effects was reported by Tchiagam et al. (2011). Plant height, collar diameter and leaves per plant also displayed the prevalence of non-additive effects as their GCA/SCA value was lower than unity (Biabani et al. 2012; Vaghela et al. 2011). General combining ability variances for majority of the characters showed that genetic advance is achievable through selection. Higher positive and significant GCA effects showed that parents $\mathrm{P}_{1}, \mathrm{P}_{2}$ and $\mathrm{P}_{3}$ were the best general combiner for most of the traits (Table 2). The remaining three parents $\left(\mathrm{P}_{4}, \mathrm{P}_{5}\right.$ and $\left.\mathrm{P}_{6}\right)$ were the poor general combiner for maximum characters 
TABLE 1. Combining ability ANOVA for seed yield and its related characters in jatropha

\begin{tabular}{lccccccccc}
\hline $\begin{array}{l}\text { Sources of } \\
\text { variation }\end{array}$ & df & IPP & FPI & FPP & SPF & SPP & HSW & SYP \\
\hline gca & 5 & $6.50 * *$ & $10.56 * *$ & $1975.1 * *$ & $0.13 * *$ & $16652.1 * *$ & $59.40 * *$ & $8917.3 * *$ & $10.79 * *$ \\
sca & 15 & $7.75 * *$ & $3.78 * *$ & $1832.7 * *$ & $0.07 * *$ & $15863.1 * *$ & $47.77 * *$ & $6860.1 * *$ & $10.56 * *$ \\
Error & 40 & 0.45 & 0.44 & 52.5 & 0.01 & 382.1 & 0.35 & 148.8 & 0.05 \\
gca $:$ sca & & 0.84 & 2.79 & 1.08 & 1.85 & 1.05 & 1.24 & 1.30 \\
\hline
\end{tabular}

* \& **, significance at 0.05 and 0.01 level

TABLE 2. GCA effects for seed yield and its components of six parents of jatropha

\begin{tabular}{lcccccccc}
\hline Parents & IPP & FPI & FPP & SPF & SPP & HSW & SYP \\
\hline $\mathrm{P}_{1}$ & $1.06 * *$ & $1.80 * *$ & $24.15 * *$ & $0.12 * *$ & $66.98 * *$ & $3.33 * *$ & $52.44 * *$ \\
$\mathrm{P}_{2}$ & $0.26 \mathrm{~ns}$ & $0.51 \mathrm{~ns}$ & $4.99 *$ & $0.09 * *$ & $16.63 *$ & $-1.08 * *$ & $8.63 \mathrm{~ns}$ & $-1.15 * *$ \\
$\mathrm{P}_{3}$ & $0.81 *$ & $-0.40 \mathrm{~ns}$ & $4.99 *$ & $0.13 * *$ & $20.13 * *$ & $-0.17 \mathrm{~ns}$ & $15.93 * *$ & $0.13 \mathrm{~ns}$ \\
$\mathrm{P}_{4}$ & $-0.40 \mathrm{~ns}$ & $-0.40 *$ & $-7.60 * *$ & $-0.13 * *$ & $-28.13 * *$ & $-4.17 * *$ & $-24.53 * *$ & $-1.13 * *$ \\
$\mathrm{P}_{5}$ & $-1.40 * *$ & $-1.65 * *$ & $-23.06 * *$ & $-0.18 * *$ & $-65.99 * *$ & $2.67 * *$ & $-42.31 * *$ & $0.86 * *$ \\
$\mathrm{P}_{6}$ & $-0.32 \mathrm{~ns}$ & $0.14 \mathrm{~ns}$ & $-3.47 *$ & -0.02 & $-9.62 \mathrm{~ns}$ & $-0.58 *$ & $-10.16 *$ & $0.71 * *$ \\
$\mathrm{SE}\left(\mathrm{g}_{\mathrm{i}}\right)$ & 0.21 & 0.21 & 2.34 & 0.01 & 6.31 & 0.18 & 3.93 \\
$\mathrm{SE}\left(\mathrm{s}_{\mathrm{ij}}\right)$ & 0.59 & 0.58 & 6.42 & 0.02 & 17.33 & 0.52 & 0.01 \\
\hline
\end{tabular}

$* p<0.05 ; * * p<0.01 ; \mathrm{ns}=$ non significant

except 100-seed weight and percent of oil content in seed as they possessed significant negative general combining ability effects.

Around $26 \%$ hybrids exhibited positive and significant specific combining ability effects (Table 3). Maximum positive specific combining ability effects were observed in the cross combinations of $\mathrm{P}_{1} \times \mathrm{P}_{2}, \mathrm{P}_{1} \times \mathrm{P}_{3}, \mathrm{P}_{2} \times \mathrm{P}_{5}$ and $\mathrm{P}_{4} \times \mathrm{P}_{6}$ for inflorescence per plant and fruits per inflorescence. These cross combinations could be utilized for the development of high yielding variety of jatropha with maximum seed yield and percent seed oil content. The cross combinations having both parents with high general combining ability (high $\times$ high) produced high specific combining ability effects, indicating genetic improvement through selection could be achievable for these traits. The hybrid combinations $\mathrm{P}_{1} \times \mathrm{P}_{2}, \mathrm{P}_{1} \times \mathrm{P}_{3}, \mathrm{P}_{2} \times \mathrm{P}_{5}, \mathrm{P}_{3} \times \mathrm{P}_{6}$ and $\mathrm{P}_{4} \times \mathrm{P}_{6}$ displayed positive and highly significant specific combining ability effects for seed number per plant (Table 3 ). The results of this investigation were in accordance with the findings of Kumar and Kannan (2010) and Pahlavani et al. (2007) who reported the preponderance of additive gene actions for seed number per plant, but the result was contradictory to the findings of Bhateria et al. (2006), Gravina et al. (2004) and Singh et al. (2009). The specific combining ability effects were found to be significant and positive for hundred seed weight in six hybrids and the highest positive value of SCA $(11.17 \mathrm{~g})$ in the hybrid $\mathrm{P}_{4} \times$ $\mathrm{P}_{5}$ (Table 3$)$. The cross combinations $\left(\mathrm{P}_{4} \times \mathrm{P}_{5}\right)$ having both parents with low general combining ability (low $\times$ low) produced high specific combining ability effects for seed yield per plant indicating that this trait is controlled by nonadditive genetic effects. The cross combinations $\mathrm{P}_{2} \times \mathrm{P}_{5}$, $\mathrm{P}_{2} \times \mathrm{P}_{5}$ and $\mathrm{P}_{1} \times \mathrm{P}_{3}$ exhibited high positive and significant specific combining ability effects for seed yield per plant (115.86, 118.29 and $178.92 \mathrm{~g}$, respectively; Table 3). On the other hand, the lowest specific combining ability effect (-73.51) was obtained from the hybrid combination of $\mathrm{P}_{3} \times$ $\mathrm{P}_{4}$. The opportunity of hereditary progress for these traits as the hybrid combinations involving both parents with high general combining ability effects produced high specific combining ability effects. Significant and positive SCA effects for seed oil content were observed in seven hybrid combinations and the highest effects was from $\mathrm{P}_{1} \times \mathrm{P}_{2}$ (4.26) followed by $\mathrm{P}_{3} \times \mathrm{P}_{6}$ (3.02). Significant general and specific combining ability effects and non-additive gene actions were essential for the hereditary transmission of seed yield related traits (Bajaj et al. 1997). The additive and non-additive genetic effects were also essential in the hereditary process of oil content in Ricinus communis (Okoh et al. 2007). The hybrid combinations exhibiting high specific combining ability effects for yield and yield related traits in jatropha were also involved with the parents having good $\times$ good, good $\times$ poor and poor $\times$ poor general combining ability effects. The involvement of at least one parent with high general combining ability effects and other parents with good or medium or poor general combining ability effects was also reported in several crosses by Tripathi et al. (2012). These results indicated the involvement of both additive and non-additive genetic effects for the expression of these traits.

\section{COMPONENTS OF GENETIC REGULATION}

Analysis of variance in Hayman's approach was in agreement with the results of Griffing's approach as mean squares due to additive (a) and non-additive estimates (b) were important $(p<0.01)$ for every character under 
TABLE 3. SCA effects for seed yield and yield components of 15 cross combinations of jatropha

\begin{tabular}{|c|c|c|c|c|c|c|c|c|}
\hline Hybrids & IPP & FPI & FPP & SPF & SPP & HSW & SYP & OC (\%) \\
\hline $\mathrm{P}_{1} \times \mathrm{P}_{2}$ & $3.13 * *$ & $1.08^{*}$ & $47.08 * *$ & $0.12 * *$ & $146.41 * *$ & $1.08 \mathrm{~ns}$ & $93.99 * *$ & $4.26 * *$ \\
\hline $\mathrm{P}_{1}^{1} \times \mathrm{P}_{3}^{2}$ & $4.92 * *$ & $2.66 * *$ & $85.75 * *$ & $-0.01 \mathrm{~ns}$ & $236.60 * *$ & $6.83 * *$ & $178.92 * *$ & $-0.08 n s$ \\
\hline $\mathrm{P}_{1}^{1} \times \mathrm{P}_{4}^{3}$ & $-0.88 n s$ & $-0.66 n s$ & $-7.67 \mathrm{~ns}$ & $0.03 \mathrm{~ns}$ & $-23.05 * *$ & $9.50 * *$ & $-3.09 \mathrm{~ns}$ & $-4.30 * *$ \\
\hline $\mathrm{P}_{1}^{1} \times \mathrm{P}_{5}^{4}$ & $-1.21 *$ & $0.24 \mathrm{~ns}$ & $-17.54 * *$ & $0.33 * *$ & $-36.70 * *$ & $-5.67 * *$ & $-34.13 * *$ & $1.68 * *$ \\
\hline $\mathrm{P}_{1} \times \mathrm{P}_{6}^{5}$ & $-0.63 n s$ & $0.45 \mathrm{~ns}$ & $-6.79 \mathrm{~ns}$ & $-0.09 * *$ & $-30.39 * *$ & $1.58 * *$ & $-18.99 *$ & $-2.16 * *$ \\
\hline $\mathrm{P}_{2} \times \mathrm{P}_{3}^{0}$ & $-0.96 n s$ & $-0.71 \mathrm{~ns}$ & $-16.75 * *$ & $0.06^{* *}$ & $-42.98 * *$ & $9.92 * *$ & $-14.16 n s$ & $-4.94 * *$ \\
\hline $\mathrm{P}_{2}^{2} \times \mathrm{P}_{4}^{3}$ & $-0.08 \mathrm{~ns}$ & $0.29 \mathrm{~ns}$ & $-1.17 \mathrm{~ns}$ & $0.06 * *$ & $-4.39 \mathrm{~ns}$ & $-4.08 * *$ & $-10.63 n s$ & $2.63 * *$ \\
\hline $\mathrm{P}_{2}^{2} \times \mathrm{P}_{5}^{4}$ & $4.92 * *$ & $3.20 * *$ & $70.96 * *$ & $0.34 * *$ & $206.10 * *$ & $-4.92 * *$ & $115.86^{* *}$ & $2.72 * *$ \\
\hline $\mathrm{P}_{2}^{2} \times \mathrm{P}_{6}^{5}$ & $-0.83 n s$ & $-1.26 * *$ & $-19.29 * *$ & $-0.44 * *$ & $-78.90 * *$ & $-5.67 * *$ & $-53.61 * *$ & $-0.37 \mathrm{~ns}$ \\
\hline $\mathrm{P}_{3}^{2} \times \mathrm{P}_{4}^{6}$ & $-3.29 * *$ & $-1.80 * *$ & $-40.83 * *$ & $0.01 \mathrm{~ns}$ & $-108.18 * *$ & $-7.67 * *$ & $-73.51 * *$ & $-0.65 * *$ \\
\hline $\mathrm{P}_{3}^{3} \times \mathrm{P}_{5}^{4}$ & $-2.29 * *$ & $-1.55^{*}$ & $-30.71 * *$ & $-0.09 * *$ & $-87.69 * *$ & $-3.83 * *$ & $-58.73 * *$ & $-5.66 * *$ \\
\hline $\mathrm{P}_{3}^{3} \times \mathrm{P}_{6}$ & $-0.04 n s$ & $2.99 * *$ & $19.38 \mathrm{~ns}$ & $0.27 * *$ & $70.36 * *$ & $0.75 \mathrm{~ns}$ & $41.46^{* *}$ & $3.02 * *$ \\
\hline $\mathrm{P}_{4}^{3} \times \mathrm{P}_{5}^{6}$ & $-1.08 n s$ & $-0.55 n s$ & $-11.13 n s$ & $-0.21 * *$ & $-33.82 \mathrm{~ns}$ & $11.17 * *$ & $-8.33 n s$ & $-2.02 * *$ \\
\hline $\mathrm{P}_{4}^{4} \times \mathrm{P}_{6}^{5}$ & $4.17 * *$ & $2.33 * *$ & $61.29 * *$ & $0.49 * *$ & $199.52 * *$ & $1.08 \mathrm{~ns}$ & $118.29 * *$ & $1.05 * *$ \\
\hline $\mathrm{P}_{5} \times \mathrm{P}_{6}$ & $-0.83 n s$ & $-2.09 * *$ & $-19.58 *$ & $-0.31 * *$ & $-60.96 * *$ & $8.58 * *$ & $-28.37 *$ & $1.01 * *$ \\
\hline $\operatorname{SEd}\left(\mathrm{g}_{\mathrm{i}}-\mathrm{g}_{\mathrm{j}}\right)$ & 0.33 & 0.38 & 3.62 & 0.01 & 9.77 & 0.29 & 6.09 & 0.11 \\
\hline $\operatorname{SEd}\left(\mathrm{S}_{\mathrm{ij}}-\mathrm{S}_{\mathrm{ik}}\right)$ & 0.88 & 1.00 & 9.58 & 0.03 & 25.86 & 0.78 & 16.33 & 0.30 \\
\hline
\end{tabular}

$* p<0.05 ; * * p<0.01 ; \mathrm{ns}=$ non significant

study (Table 4). The overall mean dominance deviation $\left(b_{1}\right)$ was significant $(p<0.05)$ for all the characters except the number of seeds per fruit, indicating that dominance variations of gene are largely in one direction. The significance $(p<0.01)$ of $\mathrm{b}_{1}$ and $\mathrm{b}_{2}$ components for all the characters except seed number per fruit illustrates that the dominance variation of genes are primarily in one way and uneven allocation of principal genes between the parents, respectively. The significant value of $b_{3}$ also established the existence of particular control or uniting capability in several crosses. Additive-dominance genetic effects take part in an important role in the control of expression of number of seeds per fruit. The significant value of additive (D), dominance $\left(\mathrm{H}_{1}\right)$ gene actions, ratio of desired and undesired genes $\left(\mathrm{H}_{2}\right)$ in the parental genotypes and variance components due to environment (E) imply that the variation observed for seed yield related traits and oil content were determined by additive and non-additive gene actions. The existence of non-additive genetic effects was also reported in the crosses of jatropha for plant height, collar diameter and leaf number (Biabani et al. 2012). Estimates of nonadditive components $\left(\mathrm{H}_{1}\right)$ were higher than the additive components (D) for most of the characters except number of fruits per inflorescence and seed oil content, indicating predominance of dominance and epistatic types of genetic effects. Tripathi et al. (2012) reported the significant role of dominance gene action in the inheritance of yield contributing traits of jatropha, which justifies the role of heterosis breeding for rapid improvement. Significant negative value of mean covariance of additive and dominance effects (F) for seed yield and three component traits except seed number per fruits, weight of 100-seed and amount of seed oil indicated asymmetrical sharing of gene with a surplus of recessive genes in the parental genotypes (Table 5 ). This was also confirmed by the ratio of $\left[\left(4 \mathrm{DH}_{1}\right)^{1 / 2}+\mathrm{F}\right] /\left[\left(4 \mathrm{DH}_{1}\right)^{1 / 2}-\mathrm{F}\right]$. The value of the ratio was greater than 1.0 indicating the asymmetrical distribution of dominance and recessive alleles. The significant $\mathrm{H}_{1}$ and $\mathrm{H}_{2}$ values suggested that the association of dominance and epistatic types of genetic effects for the inheritance of yield components and oil content. Therefore, it signifies the role of non-additive gene actions in the genetic regulation of yield and related traits in jatropha. The significant $h_{2}$ value indicates the existence of difference between parents and crosses (Table 5). The ratio $\left(\mathrm{H}_{1} / \mathrm{D}\right)^{1 / 2}$ greater than 1.0 indicates the presence of over dominance. Asymmetrical

TABLE 4. Hayman analysis of variances following Morley Jones modification for seed yield and yield related characters in a six parental half diallel populations (parents and hybrids) of jatropha

\begin{tabular}{cccccccccc}
\hline S/V & df & IPP & FPI & FPP & SPF & SPP & HSW & SYP & OC $(\%)$ \\
\hline $\mathrm{a}$ & 5 & $13.31^{* *}$ & $20.58^{* *}$ & $4317.9^{* *}$ & $0.22^{*}$ & $36815.9 * *$ & $98.33^{* *}$ & $19724.3 * *$ & $15.69 * *$ \\
$\mathrm{~b}$ & 15 & $30.07^{* *}$ & $19.67^{* *}$ & $6744.4^{* *}$ & $0.28^{*}$ & $57375.1 * *$ & $179.16^{* *}$ & $25272.9^{* *}$ & $37.94 * *$ \\
$\mathrm{~b}_{1}$ & 1 & $6.81^{* *}$ & $9.64^{* *}$ & $3476.0^{* *}$ & $0.09 \mathrm{~ns}$ & $30960.6 * *$ & $94.85^{* *}$ & $15085.3 * *$ & $3.95 * *$ \\
$\mathrm{~b}_{2}$ & 5 & $7.67 * *$ & $2.52^{* *}$ & $1301.5^{* *}$ & $0.02 \mathrm{~ns}$ & $8690.7 * *$ & $21.79 * *$ & $4220.9 * *$ & $13.42^{* *}$ \\
$\mathrm{~b}_{3}$ & 9 & $45.10^{* *}$ & $30.31^{* *}$ & $10131.4 * *$ & $0.44^{*}$ & $87357.0^{* *}$ & $275.92^{* *}$ & $38100.4 * *$ & $55.34 * *$ \\
Error & 40 & 0.45 & 0.43 & 52.47 & 0.01 & 400.29 & 0.34 & 156.23 & 0.05 \\
\hline
\end{tabular}

$* p<0.05 ; * * p<0.01 ; \mathrm{ns}=$ non significant 
distribution of positive and negative alleles was found as $\mathrm{H}_{2} / 4 \mathrm{H}_{1}$ was $>0.25$. The number of genes or gene groups exhibiting dominance was exhibited by the value of the ratio of $\mathrm{h}_{2} / \mathrm{H}_{2}$. The seed number per fruits $(89 \%)$ and $100-$ seed weight (93\%) showed high narrow sense heritability, which indicates the significance of additive genetic effects and higher contribution by the genetic factors to phenotypic variation. The heritability in narrow sense was $13 \%$ indicating the importance of dominance and epistatic type of gene action in the inheritance of seed yield in jatropha.

\section{ESTIMATES OF HETEROSIS}

The hybrid vigor or heterosis was estimated as percent increase or decrease of $F_{1}$ values over mean performance of two parents involved in the cross and better parent (parent with higher performance involved in the cross). Several crosses were found to be promising with highly significant and positive heterosis for yield related traits over their parents (Table 6; Figure 1). The extent of heterosis for seed yield components and seed oil content over mid and better parent varied significantly among the cross combinations. The range of heterosis, number of significant heterotic crosses and the best heterotic crosses for all the characters are presented in Table 6. Out of 15 hybrids, seven crosses showed significant positive average heterosis and four showed heterobeltiosis for inflorescence number per plant. Significant positive heterosis for number of fruits per inflorescence was observed in six crosses over better parent (Table 6) and it was generally associated with higher productivity. The average heterosis ranged from -6.71 to $16.51 \%$ for fruit number per plant, which was also associated with higher productivity. Among the 15 hybrids, 12 hybrids showed significant mid parent heterosis for fruit number per plant. Positive and higher heterobeltiosis was observed for fruit number per plant in the hybrid combinations $\mathrm{P}_{1} \times \mathrm{P}_{3}, \mathrm{P}_{2} \times \mathrm{P}_{5}, \mathrm{P}_{4} \times \mathrm{P}_{6}$ and $\mathrm{P}_{1} \times$ $\mathrm{P}_{2}$ (Figures 2 and 3 ).

Seeds per plant trait are the most essential attribute of seed yield and it is useful in breaking the yield ceiling. Thus, the hybrids with positive heterosis were desirable for

TABLE 5. Estimates of genetic components of variation and ratios for seed yield and yield related characters in a six parental half diallel populations (parents and hybrids) of jatropha

\begin{tabular}{|c|c|c|c|c|c|c|c|c|}
\hline $\begin{array}{l}\text { Sources of } \\
\text { variation }\end{array}$ & IPP & FPI & FPP & SPF & SPP & HSW & SYP & $\mathrm{OC}(\%)$ \\
\hline D & $3.02 * *$ & $1.32 *$ & $225.98 * *$ & $0.07 * *$ & $2201.32 * *$ & $31.02 * *$ & $898.14 * *$ & $12.56 * *$ \\
\hline $\mathrm{F}$ & $3.52 * *$ & $-4.02 * *$ & $-364.64 * *$ & $0.01 *$ & $-4418.61 * *$ & $12.66 * *$ & $-2918.94 * *$ & $16.26^{* *}$ \\
\hline $\mathrm{H}_{1}$ & $3.75 * *$ & $0.41 *$ & $715.63 * *$ & $0.02 *$ & $4659.83 * *$ & $13.62 * *$ & $2363.67 * *$ & $8.81 * *$ \\
\hline $\mathrm{H}_{2}$ & $26.76^{* *}$ & $12.40 * *$ & $6451.72 * *$ & $0.25 * *$ & $55254.03 * *$ & $174.09 * *$ & $23596.15^{* *}$ & $37.29 * *$ \\
\hline $\mathrm{h}_{2}^{2}$ & $3.60 * *$ & $4.37 * *$ & $56.21 * *$ & $0.46^{*}$ & $26.06^{* *}$ & $14.33 * *$ & $89.28 * *$ & $-2.99 * *$ \\
\hline $\mathrm{E}^{2}$ & $0.51^{*}$ & $0.47^{*}$ & $57.02 * *$ & $0.01 \mathrm{~ns}$ & $425.24 * *$ & $0.34^{*}$ & $168.86^{* *}$ & $0.05^{*}$ \\
\hline$\left(\mathrm{H}_{1} / \mathrm{D}\right)^{.5}$ & 1.12 & 0.56 & 1.78 & 0.46 & 1.46 & 0.66 & 2.63 & 0.84 \\
\hline $\mathrm{H}_{2} / 4 \mathrm{H}_{1}$ & 1.79 & 7.52 & 2.25 & 4.55 & 2.96 & 3.20 & 2.50 & 1.06 \\
\hline $\begin{array}{l}{\left[\left(4 \mathrm{DH}_{1}\right)^{1 / 2}+\mathrm{F}\right] /} \\
{\left[\left(4 \mathrm{DH}_{1}\right)^{1 / 2}-\mathrm{F}\right]}\end{array}$ & 3.20 & -0.46 & 0.38 & 1.29 & 0.18 & 1.89 & -0.01 & 7.80 \\
\hline $\mathrm{h}_{2} / \mathrm{H}_{2}$ & 0.13 & 0.35 & 0.01 & 1.79 & 0.01 & 0.08 & 0.01 & -0.08 \\
\hline $\mathrm{h}^{\frac{2}{2}}{ }_{\mathrm{n}}^{2}$ & 0.56 & 0.17 & 0.14 & 0.89 & 0.16 & 0.93 & 0.13 & 0.36 \\
\hline
\end{tabular}

$* p<0.05 ; * * p<0.01 ; \mathrm{ns}=$ non significant

TABLE 6. Promising hybrid combinations based on mid parent and better parent heterosis for seed yield and its related traits in jatropha

\begin{tabular}{|c|c|c|c|c|}
\hline \multirow{3}{*}{ Traits } & \multicolumn{4}{|c|}{ Number of cross with } \\
\hline & \multicolumn{2}{|c|}{ Significant heterosis over } & \multicolumn{2}{|c|}{ Significant favorable heterosis (cross with highest positive value) } \\
\hline & $\mathrm{MP}(\%$ range $)$ & $\mathrm{BP}(\%$ range $)$ & MP & $\mathrm{BP}$ \\
\hline IPP & $10(-48.00$ to 135.71$)$ & $9(-55.17$ to 135.71$)$ & $7\left(\mathrm{P}_{2} \times \mathrm{P}_{5}, \mathrm{P}_{1} \times \mathrm{P}_{2} \mathrm{P}_{1} \times \mathrm{P}_{3}, \mathrm{P}_{4} \times \mathrm{P}_{6}\right)$ & $4\left(\mathrm{P}_{2} \times \mathrm{P}_{5}, \mathrm{P}_{1} \times \mathrm{P}_{2}, \mathrm{P}_{4} \times \mathrm{P}_{6}, \mathrm{P}_{1} \times \mathrm{P}_{3}\right)$ \\
\hline FPI & $12(-22.73$ to 50.00$)$ & $10(-31.97$ to 44.06$)$ & $9\left(\mathrm{P}_{3} \times \mathrm{P}_{6}, \mathrm{P}_{1} \times \mathrm{P}_{3}, \mathrm{P}_{2} \times \mathrm{P}_{5}, \mathrm{P}_{4} \times \mathrm{P}_{6}\right)$ & $6\left(\mathrm{P}_{3} \times \mathrm{P}_{6}, \mathrm{P}_{4} \times \mathrm{P}_{6}, \mathrm{P}_{1} \times \mathrm{P}_{3}\right)$ \\
\hline FPP & $12(-6.71$ to 16.51$)$ & $10(-69.95$ to 155.25$)$ & $8\left(\mathrm{P}_{2} \times \mathrm{P}_{5}, \mathrm{P}_{1} \times \mathrm{P}_{2} \mathrm{P}_{1} \times \mathrm{P}_{3}, \mathrm{P}_{4} \times \mathrm{P}_{6}\right)$ & $6\left(\mathrm{P}_{1} \times \mathrm{P}_{3}, \mathrm{P}_{2} \times \mathrm{P}_{5} \mathrm{P}_{4} \times \mathrm{P}_{6}, \mathrm{P}_{1} \times \mathrm{P}_{2}\right)$ \\
\hline SPF & $12(-19.07$ to 25.61$)$ & $4(-3.56$ to 22.20$)$ & $7\left(\mathrm{P}_{4} \times \mathrm{P}_{6}, \mathrm{P}_{1} \times \mathrm{P}_{5} \mathrm{P}_{2} \times \mathrm{P}_{5}, \mathrm{P}_{3} \times \mathrm{P}_{6}\right)$ & $1\left(\mathrm{P}_{4} \times \mathrm{P}_{6}\right)$ \\
\hline SPP & $10(-58.85$ to 289.05$)$ & $10(-73.04$ to 201.76$)$ & $7\left(\mathrm{P}_{2} \times \mathrm{P}_{5}, \mathrm{P}_{4} \times \mathrm{P}_{6} \mathrm{P}_{1} \times \mathrm{P}_{2}, \mathrm{P}_{1} \times \mathrm{P}_{3}\right)$ & $6\left(\mathrm{P}_{2} \times \mathrm{P}_{5}, \mathrm{P}_{4} \times \mathrm{P}_{6} \mathrm{P}_{1} \times \mathrm{P}_{3}, \mathrm{P}_{1} \times \mathrm{P}_{2}\right)$ \\
\hline HSW & $14(-10.74$ to 25.66$)$ & $12(-17.19$ to 12.50$)$ & $9\left(\mathrm{P}_{2} \times \mathrm{P}_{5}, \mathrm{P}_{1} \times \mathrm{P}_{4} \mathrm{P}_{5} \times \mathrm{P}_{6}, \mathrm{P}_{1} \times \mathrm{P}_{3}\right)$ & $6\left(\mathrm{P}_{5} \times \mathrm{P}_{6}, \mathrm{P}_{2} \times \mathrm{P}_{3} \mathrm{P}_{4} \times \mathrm{P}_{5}, \mathrm{P}_{1} \times \mathrm{P}_{3}\right)$ \\
\hline SYP & $11(-58.79$ to 254.13$)$ & $9(-72.11$ to 202.36$)$ & $9\left(\mathrm{P}_{2} \times \mathrm{P}_{5}, \mathrm{P}_{4} \times \mathrm{P}_{6} \mathrm{P}_{1} \times \mathrm{P}_{3}, \mathrm{P}_{1} \times \mathrm{P}_{2}\right)$ & $5\left(\mathrm{P}_{1} \times \mathrm{P}_{3}, \mathrm{P}_{4} \times \mathrm{P}_{6} \mathrm{P}_{2} \times \mathrm{P}_{5}, \mathrm{P}_{1} \times \mathrm{P}_{2}\right)$ \\
\hline $\mathrm{OC}$ & $12(-17.44$ to 12.20$)$ & $8(-22.59$ to 2.368$)$ & $5\left(\mathrm{P}_{1} \times \mathrm{P}_{2}, \mathrm{P}_{2} \times \mathrm{P}_{4}, \mathrm{P}_{2} \times \mathrm{P}_{5}\right)$ & $1\left(\mathrm{P}_{1} \times \mathrm{P}_{2}\right)$ \\
\hline
\end{tabular}

$\mathrm{IPP}=$ inflorescence per plant (no.), $\mathrm{FPI}=$ fruits per inflorescence (no.), $\mathrm{FPP}=$ fruits per plant (no.), $\mathrm{SPF}=$ seeds per fruit (no.), $\mathrm{SPP}=$ seeds per plant (no.), $\mathrm{HSW}=100$-seed weight $(\mathrm{g}), \mathrm{SYP}=$ seed yield per plant $(\mathrm{g}), \mathrm{OC}=$ oil content $(\%)$ 

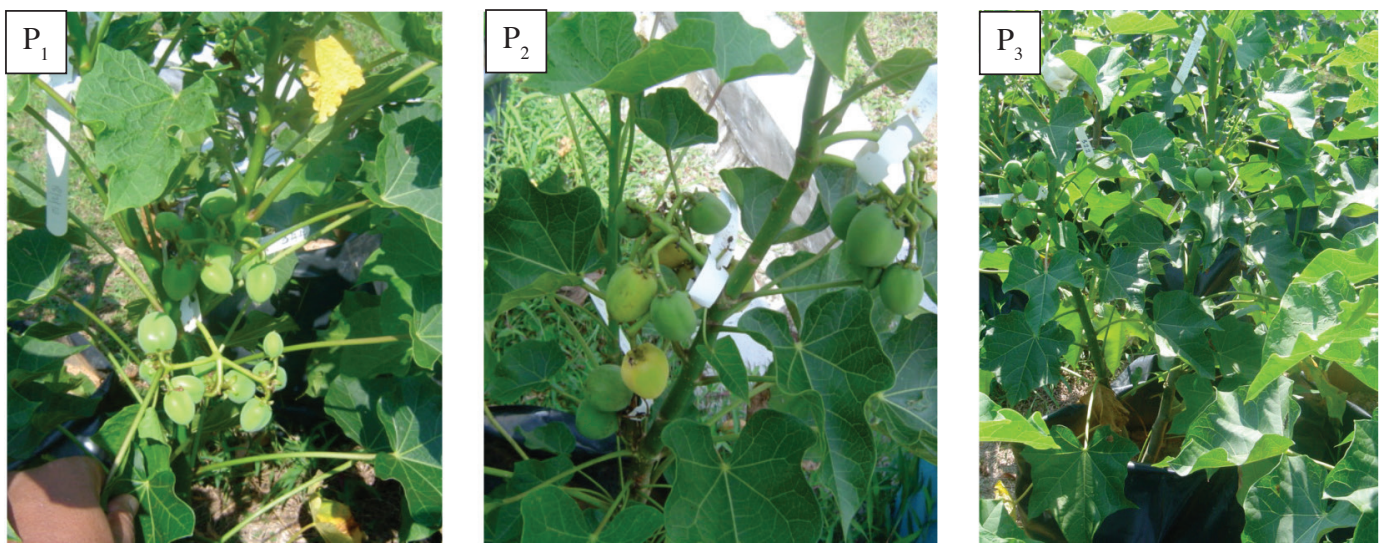

FIGURE 1. Plants with inflorescence and fruits of three parents $\left(\mathrm{P}_{1}, \mathrm{P}_{2}\right.$ and $\left.\mathrm{P}_{3}\right)$ involved in hybridization
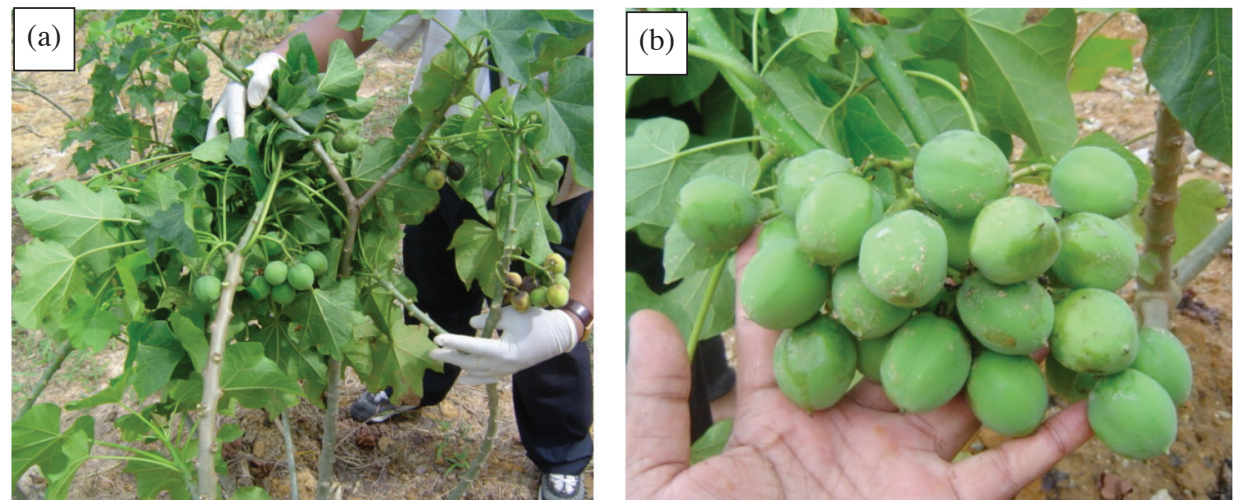

FIGURE 2. Promising hybrid $\mathrm{P}_{1} \times \mathrm{P}_{3}$ (a) plants with many inflorescence and (b) inflorescence with higher number of fruits
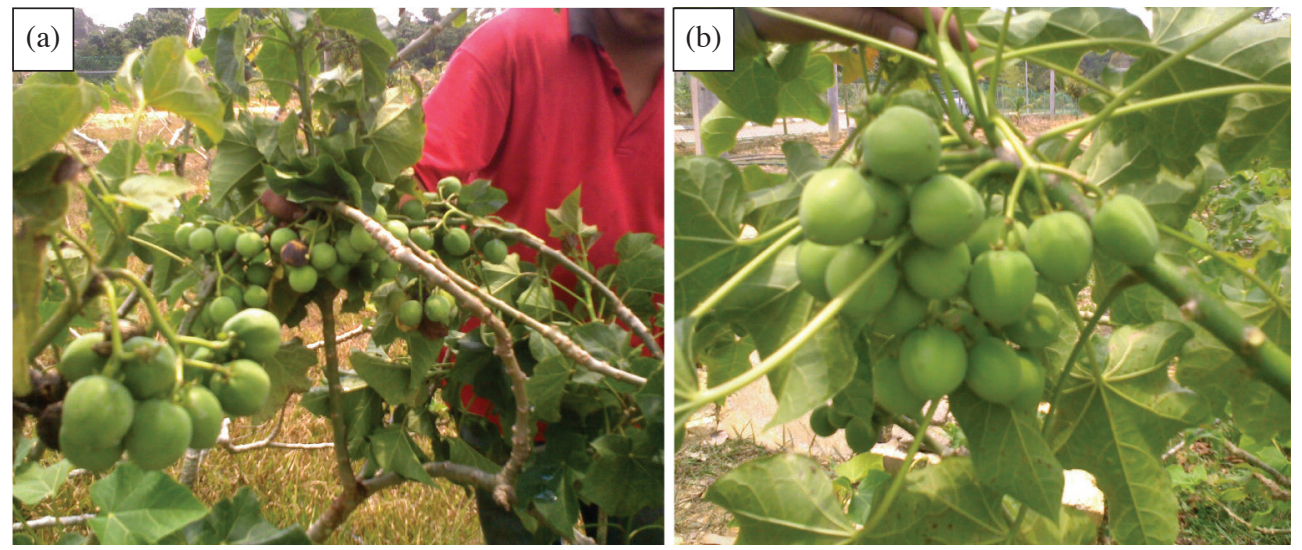

FIGURE 3. Promising hybrid $\mathrm{P}_{1} \times \mathrm{P}_{2}$ (a) plants with several inflorescence and (b) inflorescence with number of fruits

this important trait. Significant average heterosis ranged from -58.85 to $289.05 \%$ and better parent heterosis from -73.04 to $201.76 \%$ for seeds per plant (Table 6). Seven crosses showed significant positive mid parent heterosis whereas six cross combinations showed heterobeltiosis. Significant positive heterosis ranged from 35.40 to $254.13 \%$ over mid parent and 42.38 to $202.36 \%$ over better parent for seed yield per plant. Out of 15 hybrids, nine and five hybrids recorded significant and enviable average and better parent heterosis, respectively (Table 6). The significant positive average and better parent heterosis for one or more important yield components including oil content was found to accompany with seed yield per plant in jatropha. This emphasizes that high degree of heterosis in seed yield might be due to heterosis observed in one or more of the important component traits. High average 
heterosis for seed yield in jatropha was also reported by Tar et al. (2011) which varied from 32 to $262 \%$. High association of heterosis between yield and its components has also been reported earlier (Sridhar et al. 2009; Thakker et al.2005). High heterosis to the extent of $328 \%$ for seed yield was reported earlier by Singh et al. (1983). Highly significant increases of standard heterosis from 67.92 to $369.27 \%$ in hybrids were also observed for seed yield per plant (Joshi et al. 2002).

\section{CONCLUSION}

General combining ability variation was found to be greater in extent compared to specific combining ability variances for all the traits except the number of inflorescence per plant, suggesting the significance of additive genetic effects. Parent $\mathrm{P}_{1}$ was observed as the best general combiner for seed yield and related traits. On the other hand, parent $\mathrm{P}_{5}$ was found as the poor general combiner except for 100 -seed weight. The results obtained in the combining ability analysis were also in accordance with the estimates of components of variation. The amount of average heterosis and heterobeltiosis differs from hybrids to hybrids for seed yield and its components. The cross combinations of $\mathrm{P}_{1} \times \mathrm{P}_{2}, \mathrm{P}_{1} \times \mathrm{P}_{3}, \mathrm{P}_{2}$ $\times \mathrm{P}_{5}$ and $\mathrm{P}_{4} \times \mathrm{P}_{6}$ showed phenotypic superiority over their parents in respect of inflorescence per plant, fruits per inflorescence, fruits per plant, 100-seed weight and they were found to be promising for seed yield per plant. The published report on nature and extent of gene action for yield contributing traits of jatropha is scarce. Therefore, the results from this study could not be possible to compare with other findings related to jatropha. The outcome of this finding will help plant breeders for yield improvement in jatropha.

\section{ACKNOWLEDGMENTS}

The project was financed by Universiti Kebangsaan Malaysia, under the Grants UKM-AP-2012-008 and UKMDPP-2013-108.

\section{REFERENCES}

Bajaj, R.K., Aujla, K.K. \& Chalal, G.S. 1997. Combining ability studies in sunflower (Helianthus annuus L.). Crop Improv. 24: 50-54.

Bhateria, S., Sood, S.P. \& Pathania, A. 2006. Genetic analysis of quantitative traits across environments in linseed (Linum usitatissimum L.). Euphytica 150: 185-194.

Biabani, A., Rafii, M.Y., Saleh, G., Shabanimofrad, M. \& Latif, M.A. 2012. Combining ability analysis and evaluation of heterosis in Jatropha curcas L. $\mathrm{F}_{1}$ hybrids. Aust. J. Crop Sci. 6: 1030-1036.

Burton, G.W. 1968. Heterosis and heterozygosis in pear millet forage production. Crop Sci. 8: 229-230.

El-Bramawy, M.A.S. \& Shaban, W.I. 2007. Nature of gene action for yield, yield components and major diseases resistance in sesame (Sesamum indicum L.). Res. J. Agric. Biol. Sci. 3: 821-826.
Evenson, R.E. \& Gollin, D. 2003. Assessing the impact of the green revolution, 1960 to 2000. Science 300: 758-762.

Falconer, D.S. \& Mackey, F.C. 1996. Introduction to Quantitative Genetics. New York: Longman Pub. Group.

Gravina, G.D.A., Sediyama, C.S., Filho, S.M., Moreira, M.A., de Barros, E.G. \& Cruz, C.D. 2004. Multivariate analysis of combining ability for soybean resistance to Cercospora sojina Hara. Genet. Mol. Biol. 27: 395-399.

Griffing, B. 1956. Concept of general and specific combining ability in relation to diallel crossing systems. Aust. J. Biol. Sci. 9: 463-493.

Gunaseelan, V.N. 2009. Biomass estimates, characteristics, biochemical methane potential, kinetics and energy flow from Jatropha curcus on dry lands. Biomass and Bioenergy 33: 589-596.

Hayman, B.I. 1954a. The analysis of variances of diallel table. Biometrics 10: 235-244.

Hayman, B.I. 1954b. The theory and analysis of diallel crosses. Genetics 39: 789-809.

Henning, R. 2000. The Jatropha Manual - A Guide to the Integrated Exploitation of the Jatropha Plant in Zambia. Choma: GTZ.

Islam, A.K.M.A. 2011. Improvement of biodiesel production through genetic studies of Jatropha curcas. PhD Thesis. Universiti Kebangsaan Malaysia.p. 254 (Unpublished).

Islam, A.K.M.A., Anuar, N., Yaakob, Z. \& Osman, M. 2009. Selection of candidate plus plants (CPPs) on the basis of phenotypic characters in Jatropha curcas L. Agriculture Congress 2009: Tropical Agriculture in a Changing Climate and Energy Scenario, UPM, 27-29 October.

Jayasingh, J.M. 2004. The use of biodiesel by the Indian railways. In Jatropha and Other Perennial Oilseed Crop BAIF Development Research Foundation, edited by Hegde, D.M., Daniel, J.N. \& Dhar, S. India: Pune.

Jongschaap, R.E.E., Corre, W.J., Bindraban, P.S. \& Brandenburg, W.A. 2007. Claims and facts on Jatropha curcas L. global Jatropha curcas evaluation, breeding and propagation program. The Netherlands: Plant Research International B.V. Wageningen.

Joshi, H.J., Mehta, D.R. \& Jado, B.S. 2002. Heterosis for seed yield and its components, in castor hybrids. Indian J. Agric. Res. 36: 264-268.

Kumar, P.S. \& Kannan, B. 2010. Studies on general and specific combining ability in sesame (Sesamum indicum L.). Electron. J. Plant Breed. 1: 1405-1408.

Kumar, A.\& Sharma, S. 2008. An evaluation of multipurpose oil seed crop for industrial uses (Jatropha curcas L.): A review. Ind. Crop Prod. 28: 1-10.

Liang, G.H., Reddy, C.R. \& Dayton, A.D. 1971. Heterosis, inbreeding depression and heritability estimates in a systematic series of grain sorghum genotypes. Crop Sci. 12: 400-411.

Mandpe, S., Kadlaskar, S., Degen, W. \& Keppeler, S. 2005. On road testing of advanced common rail diesel vehicles with biodiesel from the Jatropha curcas plants. Society Automotive Eng. Inc. 26: 356-364.

Morley-Jones, R. 1965. The analysis of variance of the half-diallel table. Heredity 20: 117-121.

Okoh, J.O., Ojo, A.A. \& Vange, T. 2007. Combining ability and heterosis of oil content in six accessions of castor at Makurdi. Nat. Sci. 5: 18-23.

Pahlavani, M.H., Saeidi, G. \& Mirloh,A.F. 2007. Genetic analysis of seed yield and oil content in safflower using $F_{1}$ and $F_{2}$ progenies of diallel crosses. Intl. J. Plant Prod. 1: 129-140. 
Pal, B.P. \& Sikka, S.M. 1956. Exploitation of hybrid vigour in the improvement of crop plants, fruits and vegetables. Indian J. Genet. Plant Breed. 16: 95-193.

Panse, V.G. \& Sukhatme, P.V. 1978. Statistical Methods for Agricultural Workers. New Delhi: ICAR Publication.

Punia, M.S. 2007. Cultivation and use of jatropha for bio-diesel production in India. Status Paper on Different Aspects of Jatropha Plantation and Processing. India: National Oilseeds and Vegetable Oils Development Board, Ministry of Agriculture, Government of India.

Sharma, J.R. 1998. Statistical and Biometrical Techniques in Plant Breeding. Delhi, India: New Age International (P) Limited.

Sharma, S. \& Kumar, A. 2010. Jatropha curcas: A source of energy and other applications. In Energy Crops, edited by Halford, N.G. \& Karp, A. London: The Royal Society of Chemistry. pp. 196-232.

Shull, G.H. 1952. Beginnings of the heterosis concept. In Heterosis, edited by Gowen, J.W. Ames: Iowa State College Press. pp. 14-48.

Singh, P.K., Srivastava, R.L., Narain, V. \& Dubey, S.D. 2009. Combining ability and heterosis for seed yield and oil content in linseed (Linum usitatissimum). Indian J. Agric. Sci. 79: 229-232.

Singh, R.K. \& Chaudhary, B.D. 1985. Biometrical Methods in Quantitative Genetic Analysis. New Delhi: Kalyani Publication.

Singh, V.K., Singh, H.G. \& Chauhan, Y. 1983. Heterosis in sesame. Indian J. Agric. Sci. 53: 305-310.

Sridhar, V., Dangi, K.S., Reddy, A.V., Sudhakar, R. \& Sankar, A.S. 2009. Heterosis for seed yield and yield components in Castor (Ricinus communis L.). Intl. J. Agric. Environ. Biotech. 2: 64-67.

Tar, M.M., Tanya, P. \& Srinives, P. 2011. Heterosis of agronomic characters in jatropha (Jatropha curcas L.). Kasetsart J. (Nat. Sci.) 45: 583-593.

Tchiagam, J.B.N., Bell, J.M., Nassourou, A.M., Njintang, N.Y. \& Youmbi, E. 2011. Genetic analysis of seed proteins contents in cowpea (Vigna unguiculata L. Walp.). Afr. J. Biotech. 10: 3077-3086.

Thakker, D.A., Jadon, B.S., Patel, K.M. \& Patel, C.J. 2005. Heterosis over environments for seed yield and other attributes in castor (Ricinus communis L). J. Oilseed Res. 22: 324-326.

Townsend, T., Segura, V., Chigeza, G., Penfield, T., Rae, A., Harvey, D., Bowles, D. \& Graham, I.A. 2013. The use of combining ability analysis to identify elite parents for Artemisia annua $\mathrm{F} 1$ hybrid production. PLOS One 8: 1-11.
Tripathi, Y.K., Kumar, R.,Parul, S., Gupta, V.K. \& Handa, A.K 2012. Gene action and combining ability analysis for seed yield components of Jatropha curcas L. Range Manag. Agrofor. 33: 133-137.

Vaghela, P.O., Thakkar, D.A., Bhadauria, H.S., Sutariya, D.A., Parmar, S.K. \& Prajapati, D.V. 2011. Heterosis and combining ability for yield and its component traits in Indian mustard [Brassica juncea (L.)]. J. Oilseed Brassica 2: 39-43.

Wynne, J.C., Emery, D.A. \& Rice, P.H. 1970. Combining ability estimation in Arachis hypogaea L. 11. field performance of $\mathrm{F}_{1}$ hybrids. Crop Sci. 10: 713-715.

A.K.M. Aminul Islam*, Nurina Anuar \& Zahira Yaakob Department of Chemical and Process Engineering Faculty of Engineering \& Built Environment Universiti Kebangsaan Malaysia 43600 Bangi, Selangor Darul Ehsan Malaysia

A.K.M. Aminul Islam*

Department of Genetics and Plant Breeding Faculty of Agriculture

Bangabandhu Shiekh Mujibur Rahman

Agricultural University

Gazipur 1706, Bangladesh

Jaharah A. Ghani

Department of Mechanical and Material Engineering, Faculty of Engineering \& Built Environment Universiti Kebangsaan Malaysia 43600 Bangi, Selangor Darul Ehsan Malaysia

Mohamad Osman

Faculty of Plantation and Agrotechnology

Universiti Teknologi MARA (UiTM)

40450 Shah Alam, Selangor Darul Ehsan

Malaysia

*Corresponding author; email: aminuljkkp@yahoo.com

Received: 23 April 2014

Accepted: 5 February 2015 